\title{
GROWTH PERFORMANCE OF DIPTEROCARP SPECIES PLANTED ON ABANDONED MINING AREA IN SOUTHERN THAILAND**
}

\author{
JETSADA WONGPROM* \\ Faculty of Forestry, Kasetsart University, Bangkok 10900, Thailand \\ Received 17 December 2018 / Accepted 16 September 2019
}

\begin{abstract}
Dominant Dipterocarp trees hold a significant importance in the ecology and economics of the declining tropical forests of Asia. Of equal importance is the restoration of these Dipterocarp forest using the technique of matching species with silvicultural practices. The study aimed to investigate the effect of the Acacia mangium nurse trees on the survival and growth of six Dipterocarp species planted on abandoned mining areas in the Phangnga Forestry Research Station, Thailand, namely; Dipterocarpus alatus Roxb., Dipterocarpus gracilis Blume, Hopea odorata Roxb., Shorea gratissima (Wall. ex Kurz) Dyer, Shorea roxburghii G. Don, and Parashorea stellata Kurz. The approximately 1.5-year-old Dipterocarp seedlings were planted at a 6 -year-old $A$. mangium plantation cover and at open plots. The survival rate, diameter at root collar $\left(\mathrm{D}_{0}\right)$, total height $(\mathrm{H})$ and the relative growth rate $(\mathrm{RGR})$ of $\mathrm{D}_{0}$ and $\mathrm{H}$ of the seedlings were compared. Soil samples at the open and the A. mangium plots were collected and its physical and chemical properties were analyzed. The results indicated that the survival rates of the Dipterocarps planted at the $A$. mangium plot were higher than those at the open plots. The survival rates (75$100 \%$ ) of the 1 to 3-year-old D. alatus, H. odorata, S. gratissima, S. roxburghii, and P. stellata were relatively high at the $A$. mangium plot, but not for $D$. gracilis. The $\mathrm{D}_{0}$ of $S$. roxburgbii, $D$. alatus, $H$. odorata, and $P$. stellata were higher at the $A$. mangium plot. However, the $\mathrm{D}_{0}$ and $\mathrm{H}$ of $S$. roxburghii, D. alatus, and $H$. odorata at the open plot were high and similar to that of the $A$. mangium plot. $\mathrm{RGR}_{\mathrm{D} 0}$ and $\mathrm{RGR}_{\mathrm{H}}$ of $S$. roxburgbii, D. alatus, and $H$. odorata were high both at the $A$. mangium and the open plots. Generally, the Dipterocarp seedlings were growing better under the $A$. mangium nurse trees, thus suggesting the possibility of their improved survival and growth in mined out areas. Moreover, the findings also suggest that $S$. roxburghii, D. alatus, and $H$. odorata can be planted at open areas with poor soil conditions and extreme environments. Lastly, thinning interventions are also needed to improve the growth of Dipterocarp trees.
\end{abstract}

Keywords: Dipterocarp species, growth performance, mining area, Phangnga Forestry Research Station

\section{INTRODUCTION}

Dipterocarp trees mostly dominate the Asian tropical rain forests (Ghazoul 2016). These species are widely planted for forest ecosystem maintenance and for the restoration of degraded lands (Kettle 2010; Yeong et al. 2016; Budiharta et al. 2018). With the diminishing non-timber forest products, these Dipterocarp trees have become an important component of the rural livelihoods.

\footnotetext{
${ }^{*}$ Corresponding author, e-mail: fforcrw@ku.ac.th

**This paper was presented at the $3^{\text {rd }}$ International Conference on Tropical Biology 2018, 20-21 September 2018, Bogor, West Java, Indonesia
}

Illegal logging and conversion of forests to agricultural lands, mainly for oil palm and rubber, plantations has dramatically resulted in deforestation and forest loss (Appanah et al. 2016; Ghazoul 2016). Hence, forest restoration has become one the options left throughout the region of Southeast Asia (Appanah et al. 2016). Dipterocarp trees have been widely planted for commercial, conservation, and agroforestry purposes as well as forest restoration (Sakai et al. 2014; Appanah et al. 2016; Ghazoul 2016). However, those trees planted on open and degraded lands has low survival and growth rates (Hattori et al. 2013). Forest rehabilitation with Dipterocarp trees generally plant nurse 
trees using the line, strip, and gap methods (Norisada et al. 2005; Hattori et al. 2013; Sakai et al. 2014; Budiharta et al. 2014). Providing nurse trees for Dipterocarp trees significantly influenced the growth and survival of Dipterocarp seedlings (Norisada et al. 2005; Sakai et al. 2014). Moreover, environmental factors such as light, air temperature and soil properties also improved and thereby, enhanced the growth performance of Dipterocarp trees (Norisada et al. 2005; Sakai et al. 2014). Forest restoration using native tree species with appropriate silvicultural practices significantly contribute in the recovery of forest structure, diversity, and ecological services by improving tree growths and enhancing natural regeneration.

A. mangium is a fast-growing, nitrogen fixing tree commonly planted in commercial plantations and used for rehabilitation of degraded lands in Southeast Asia, including Thailand (Norisada et al. 2005; Sakai et al. 2011). Compared with other fast-growing and native tree species, its survival and growth rates on abandoned mining area are relatively higher (Martpalakorn 1990). Forest plantations do not only provide wood, but also simultaneously improve the ecosystems. Soil properties, nutrient cycling and biodiversity have been reportedly improved and restored after plantation establishment (Parrotta 1999; Lanuza et al. 2018), particularly under $A$. mangium plantation. Soil nutrients and organic matter contents were remarkably increased (Kongchum et al. 2016).

Globally, mining operations have severely impacted the environment, particularly, the soil properties, resulting to very low soil nutrient levels with strong acidic soil $\mathrm{pH}$. The soil structure becomes unsuitable for planting tree species (Oktavia et al. 2015). In addition, mining also destroys the existing vegetation. Hence, the restoration of previously mined areas has been undertaken on many sites using the plantation approach (Bohre \& Chaubey 2014; Kongchum et al. 2016). However, the forest structure and diversity levels are usually low. As such, plantation using mixed species are then recommended for restoration of degraded lands, including at post-mining sites (Lamb 2014), but the survival and growth rate of seedlings depend much on the tree species, environmental factors
(Norisada et al. 2005; Sakai et al. 2014; Lestari et al. 2019), and silvicultural practices (Sakai et al. 2011; Sakai et al. 2014). To recover the forest structure, diversity and functions, the restoration of mined out areas using indigenous tree species has been going on for a long time. Moreover, tree selection for such degraded lands and appropriate management intervention for nurse trees, such as thinning, are such important steps needed to promote the growth of native trees (Sakai et al. 2014). Understanding the influence of silvicultural practices on the growth performance of Dipterocarp trees is very critical in any restoration program. Thus, the objectives of this study were to (1) investigate and compare the survival and growth performance of Dipterocarp seedlings planted at a 6 -year-old $A$. mangium plantation and at open plots in a mined out area and, (2) to investigate the influence of thinning the A. mangium stand on the growth of Dipterocarp seedlings growing on mined out areas.

\section{MATERIALS AND METHODS}

\section{Study Site and Experimental Plot}

The experimental plot was located in an abandoned tin mine at the Phangnga Forestry Research Station, Thakuapa District, Phangnga Province, Thailand. The Province experiences the rainy season during April-November and the dry season during December-March. Its mean annual rainfall is $3,649.4 \mathrm{~mm}$ per year and the relative humidity is around $83.7 \%$ (Wongprom et al. 2013). The post mined area has a high bulk density and very low soil nutrient levels (Kongchum et al. 2016).

\section{Species}

Using completely randomized design with three replications, six species of approximately 1.5-year-old nursery-raised Dipterocarp seedlings were planted both at the open and A. mangium plots (Fig. 1). The species chosen were Dipterocarpus alatus Roxb. ex. G. Don, D. gracilis Blume, Hopea odorata Roxb., Shorea gratissima (Wall. ex Kurz) Dyer, S.roxburgbii G. Don, and Parashorea stellata Kurz. Thirty Dipterocarp seedlings were planted in a $15 \mathrm{x}$ $15 \mathrm{~m}$ plot with a spacing of $3 \times 3 \mathrm{~m}$ at the open 
plot, and thirty Dipterocarp seedlings at the $A$. mangium plot were planted with a spacing of 3 x $3 \mathrm{~m}$ between the rows of 6-year-old $A$. mangium. The original spacing of the $A$. mangium plot was $3 \times 3 \mathrm{~m}$. Weeding and liana cutting were practiced two times a year. Growth performances of 1 to 3-year-old Dipterocarp seedlings after planting, including the survival rate, diameter at root collar $\left(\mathrm{D}_{0}\right)$, and total height $(\mathrm{H})$, were measured.

At the $A$. mangium plot, the number of 7 year-old $A$. mangium trees was reduced to $50 \%$ using the row thinning method. The crown cover at the $A$. mangium plot was evaluated before and after thinning by using hemispherical photographs taken at 5 points by a digital camera (Nikon Coolpix 4500 with a fisheye lens) set on a tripod at $1.2 \mathrm{~m}$ above the ground. The cover was analyzed using Hemiview 2.1 (Delta-T Device Ltd.). Moreover, diameter at breast height $(\mathrm{DBH})$, height, density and crown cover of the 6 to 8 -year-old $A$. mangium trees were also measured (Table 1).

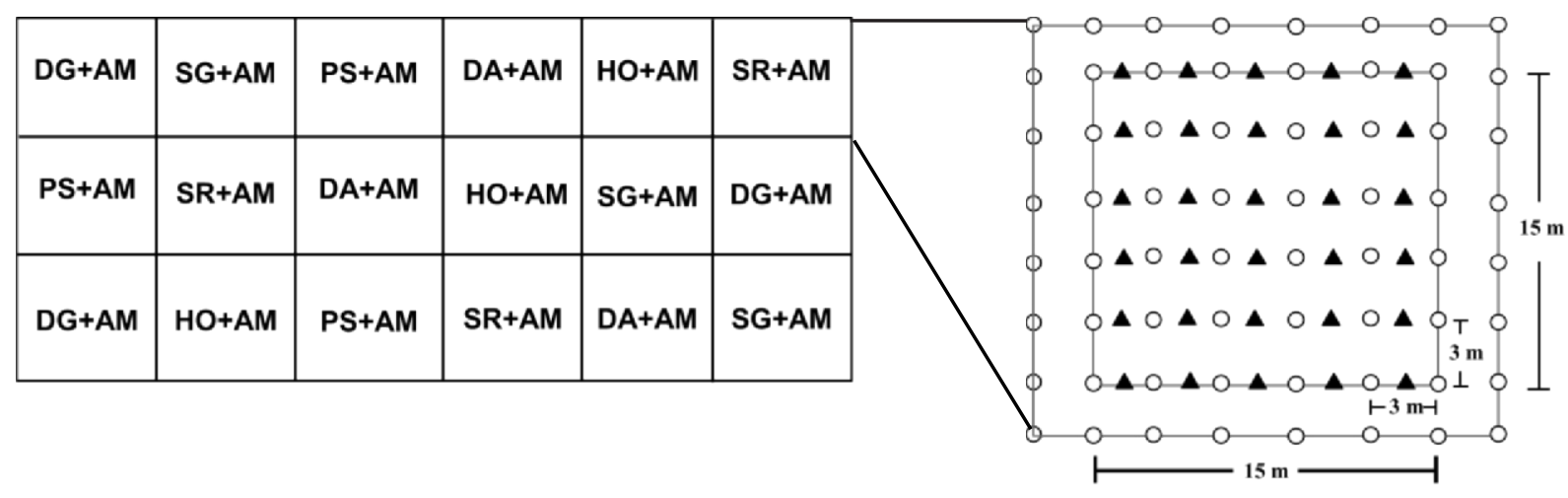

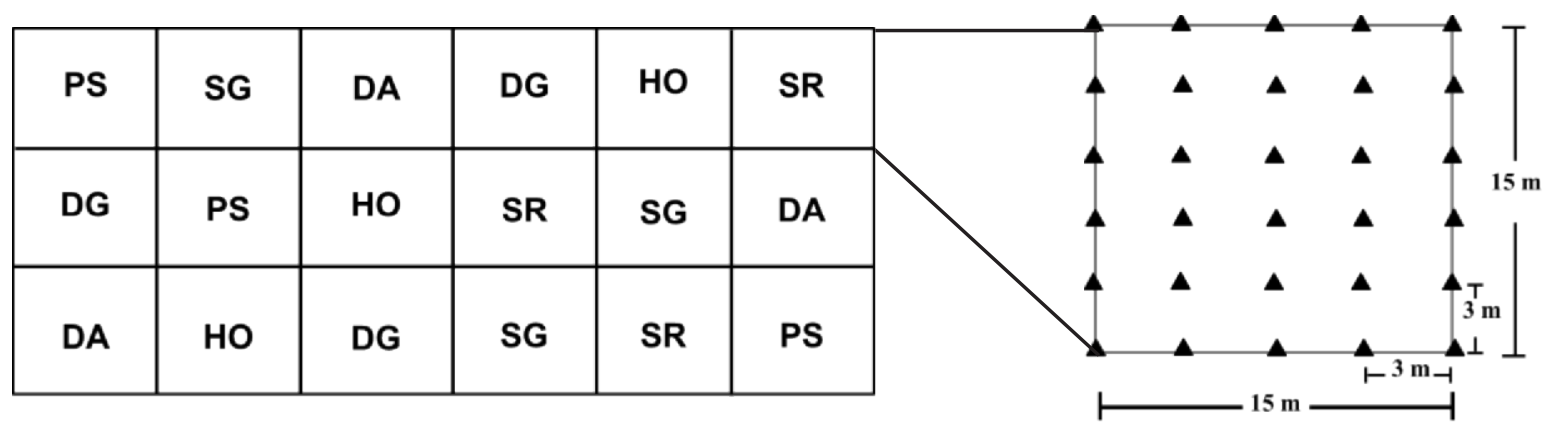

Figure 1 Layout of Dipterocarp seedling planted at the open and at the A. mangium plots

Notes: $\mathrm{AM}=$ Acacia mangium, $\mathrm{DG}=$ Diptertocarpus gracilis, $\mathrm{DA}=$ Dipterocarpus alatus, $\mathrm{SR}=$ Shorea roxburgii, $\mathrm{SG}=$ Shorea gratissima, $\mathrm{HO}=$ Hopea odorata, $\mathrm{PS}=$ Parashorea stellata); filled triangle $(\boldsymbol{\Delta})=$ Dipterocarp seedlings and the open circle $(\mathbf{0})=A$. mangium.

Table 1 Density, diameter at breast height (DBH), height $(\mathrm{H})$, and crown cover of the 6 to 8 -year-old $A$. mangium plot growing on the mined out area in Phangnga Forestry Research Station

\begin{tabular}{cccccc}
\hline $\begin{array}{c}\text { Age } \\
\text { (year) }\end{array}$ & $\begin{array}{c}\text { Density } \\
(\text { tree } / \text { ha })\end{array}$ & $\begin{array}{c}\text { Mean DBH } \\
(\mathrm{cm})\end{array}$ & $\begin{array}{c}\text { Mean } \mathrm{H} \\
(\mathrm{m})\end{array}$ & $\begin{array}{c}\text { Crown cover } \\
(\%)\end{array}$ & Remark \\
\hline 6 & 943.75 & 14.14 & 13.89 & 71.16 & - \\
7 & 471.87 & 15.60 & 14.46 & 23.92 & thinned A. mangium \\
8 & 425.00 & 16.86 & 15.76 & - & - \\
\hline
\end{tabular}




\section{Soil Properties}

Soil samples were taken from two soil depths, i.e., topsoil $(0-10 \mathrm{~cm})$ and subsoil (20-30 $\mathrm{cm})$, using a split tube sampler at three random locations from both the open and $A$. mangium plots. Soil physical properties including soil particle and soil texture, as well as soil chemical properties were measured. Organic matter content $(\mathrm{OM})$ was analyzed using the Walkley and Black's rapid titration method. The available phosphorus (P) was extracted using the Bray II method (Bray \& Kurtz 1945) and was analyzed using a spectrometer. Exchangeable potassium $(\mathrm{K})$, calcium $(\mathrm{Ca})$ and magnesium $(\mathrm{Mg})$ were extracted using $1 \mathrm{~N} \mathrm{pH} 7.0$ ammonium acetate $\left(\mathrm{NH}_{4} \mathrm{OAc}\right)$ and analyzed using an atomic absorption spectrometer (Estefan et al. 2013). Soil moisture of the topsoil and subsoil, both at the open and $A$. mangium plots, were measured monthly for 1 year after planting of the Dipterocarp trees. The collected soils were oven-dried at $80{ }^{\circ} \mathrm{C}$ for 48 hours to constant weight.

\section{Data Analyses}

Relative growth rate (RGR) of $\mathrm{D}_{0}\left(\mathrm{RGR} \mathrm{D}_{0}\right)$ and $\mathrm{H}\left(\mathrm{RGR}_{\mathrm{H}}\right)$ was calculated using the formula: $\mathrm{RGR}_{\mathrm{D} 0}=\left(\ln \mathrm{D}_{0} 2-\ln \mathrm{D}_{0} 1\right) /(\mathrm{t} 2-\mathrm{t} 1)$

$\mathrm{RGR}_{\mathrm{H}}=(\ln \mathrm{H} 2-\ln \mathrm{H} 1) /(\mathrm{t} 2-\mathrm{t} 1)$

where $\mathrm{D}_{0} 1$ and $\mathrm{D}_{0} 2$ are diameter at root collar and $\mathrm{H} 1$ and $\mathrm{H} 2$ are height at times $\mathrm{t} 1$ and $\mathrm{t} 2$.

The survival rate, $\mathrm{D}_{0}, \mathrm{H}, \mathrm{RGR}_{\mathrm{D} 0}$, and $\mathrm{RGR}_{\mathrm{H}}$ of the six Dipterocarp seedlings, both at the open and $A$. mangium plots, were compared and tested using the one way analysis of variance (ANOVA) with the Duncan's Multiple Range Test (DMRT).

\section{RESULTS AND DISCUSSION}

\section{Soil Properties}

Most of the soil particles at the experimental plots were more than $80 \%$ sand particles. Soil texture at both the open and $A$. mangium plots were of a loamy and sandy types for the topsoil and subsoil, respectively, while the soil $\mathrm{pH}$ was strongly acidic. The soil nutrient levels in the topsoil layer, including the exchangeable $\mathrm{K}$ (21.92 ppm), Ca (109.52 ppm), Mg (18.38 ppm), and available $\mathrm{P}$ (2.33 ppm), were very low (Table $2)$, except OM content $(2.50 \%)$, which was at a moderate level (USDA 1967). These low levels of soil nutrients in such areas are a result of intense mining. However, the levels of exchangeable $\mathrm{K}, \mathrm{Ca}, \mathrm{Mg}, \mathrm{P}$ and $\mathrm{OM}$ content at the $A$. mangium plot were higher than those in a abandoned mining area (Kongchum et al. 2016). Nitrogen fixing trees, like $A$. mangium, help improved the soil properties of degraded lands, particularly in increasing the soil organic matter and nutrient content (Kongchum et al. 2016).

\section{Survival Rate}

Survival rates of the Dipterocarp seedlings significantly differed among the species, both at the open and $A$. mangium plots. One year after planting, most of the Dipterocarp seedlings at the open and $A$. mangium plots survived, ranging from 75 to $100 \%$ indicating a high survival rate. However, survival rate of the 2 and 3 -year-old Dipterocarp seedlings at the open plot decreased (Fig. 2). Three year old $S$. roxburgbii had the highest survival rate $(62.22 \%)$ followed by H. odorata $(44.44 \%)$ and D. alatus $(33.33 \%)$, while $P$. stellata, S. gratissima and $D$. gracilis did not survive at all $(100 \%$ mortality $)$

Table 2 Physical and chemical properties of soil at the open and A. mangium plots at Phangnga Forestry Research Station, southern Thailand

\begin{tabular}{|c|c|c|c|c|c|c|c|c|c|c|c|}
\hline \multirow{2}{*}{ Plot } & \multirow{2}{*}{$\begin{array}{l}\text { Soil depth } \\
\quad(\mathrm{cm})\end{array}$} & \multicolumn{3}{|c|}{ Soil particle (\%) } & \multirow{2}{*}{$\begin{array}{c}\text { Soil } \\
\text { texture }\end{array}$} & \multirow[t]{2}{*}{$\mathrm{pH}$} & \multicolumn{3}{|c|}{ Exchangeable (ppm) } & \multirow{2}{*}{$\begin{array}{c}\text { Available P } \\
\text { (ppm) }\end{array}$} & \multirow{2}{*}{$\begin{array}{l}\mathrm{OM} \\
(\%)\end{array}$} \\
\hline & & Sand & Silt & Clay & & & $\mathrm{K}$ & $\mathrm{Ca}$ & $\mathrm{Mg}$ & & \\
\hline \multirow{2}{*}{ A. mangium } & $0-10$ & 86 & 7 & 7 & LS & 4.4 & 21.92 & 109.52 & 18.38 & 2.33 & 2.50 \\
\hline & $20-30$ & 91 & 2 & 7 & S & 5.5 & 6.34 & 43.58 & 7.36 & 1.73 & 0.57 \\
\hline \multirow{2}{*}{ Open } & $0-10$ & 82 & 10 & 8 & LS & 5.1 & 37.74 & 339.40 & 18.94 & 2.04 & 2.41 \\
\hline & $20-30$ & 90 & 3 & 7 & S & 5.2 & 11.48 & 94.46 & 14.76 & 0.87 & 0.16 \\
\hline
\end{tabular}

Notes: LS = Loamy sand, $\mathrm{S}=$ Sandy. 


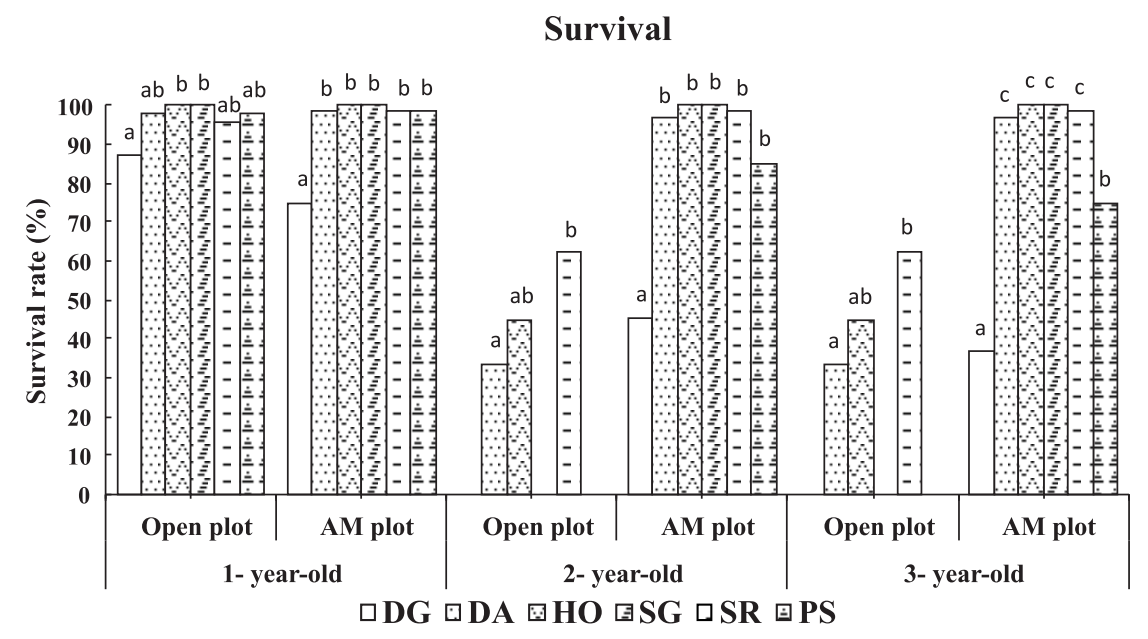

Figure 2 Survival rates of Dipterocarp trees planted at the open and at A. mangium (AM) plots

Notes: DG $=$ Diptertocarpus gracilis, DA = Dipterocarpus alatus, $\mathrm{SR}=$ Shorea roxburgii, $\mathrm{SG}=$ Shorea gratissima, $\mathrm{HO}=$ Hopea odorata, PS = Parashorea stellate;

Different letters above bars indicate significant differences at $\mathrm{p}<0.05$ among species by DMRT.

However, the Dipterocarp seedlings in the A. mangium plot had higher survival rates, between $75 \%$ and $100 \%$, except for $D$. gracilis (Fig. 2). Thinning of the A. mangium stand resulted in the mean crown cover being reduced from 71.16 to $23.92 \%$. The thinning may have negatively influenced the survival rate of $P$. stellata and $D$. gracilis seedlings. Stronger light intensity in the open areas negatively affected the survival as well as the growth of many Dipterocarp seedlings (Hattori et al. 2009). The subsequent reduction in the sunlight intensity due to the canopy of the $A$. mangium resulted in the high survival rate of the Dipterocarp seedlings (Kenzo et al. 2011). Although S. roxburghii, $H$. odorata and $D$. alatus had moderate survival rates in the open plot, these can still be planted in open areas with poor soil conditions. A study in southern Thailand, showed that these Dipterocarp species are drought and stress tolerant and can be planted on degraded sandy soil in open areas Moreover, their high survival rates, especially $S$. roxburgii, ranged between $78 \%$ and $97 \%$, when planted in an open area in a disturbed dry evergreen forest in northeastern Thailand (Niamrat \& Marod 2005). When $S$. roxburgii was planted in a grassland interspersed with bushes, its survival rate was also reportedly high (93\%) (Ang et al. 2003). Hence, rehabilitation of degraded lands using Dipterocarp seedlings is better done alongside nurse trees as these can create a microclimate suitable for the survival and growth of the seedlings.
After $A$. mangium was thinned by $50 \%$, the survival rate of $D$. gracilis and $P$. stellata decreased gradually from 75 to $36.67 \%$ and 98.33 to $75 \%$, respectively, after 3 years. The higher mortality of $D$. gracilis and $P$. stellata may have been caused by stronger light intensity. Light intensity distinctively affected the survival rates of Dipterocarp seedlings planted on degraded lands (Norisada et al. 2005; Sakai et al. 2014). High soil temperature and water stress, result in higher mortality, especially in drought conditions (Norisada et al. 2005). The sandy soil type in the study area expectedly held a very low water storage in dry season (Fig. 3), despite the fact that soil moisture significantly influences the establishment of a seedling (Hattori et al. 2013). In this study, soil moisture at $A$. mangium plot was higher than that in the open plot, indicating that $A$. mangium can reduce water transpiration from the soil. The crown cover and high amounts of litterfall from $A$. mangium create a microclimate preferable for the establishment of Dipterocarp seedlings under a mixed plantation. As the light requirements of Dipterocarps depend on the species (Sakai et al. 2014; Hattori et al. 2009), D. gracilis and P. stellata behavior showed that these may thrive well in darker conditions. Thus, to enhance the Dipterocarp seedlings survival, thinning of $A$. mangium may be delayed for mixed plot of $D$. gracilis and P. stellata. Lastly, thinning intensity is equally important in the enrichment planting of Dipterocarp seedling (Sakai et al. 2014). 

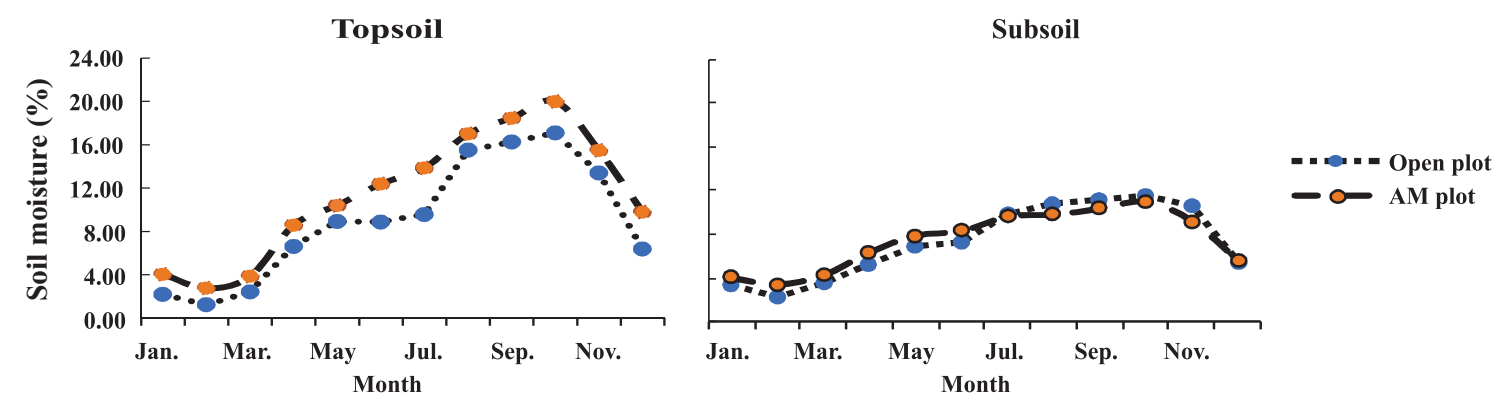

Figure 3 Soil moisture in the topsoil and subsoil levels at the open and A. mangium (AM) plots during a one-year period after planting of the Dipterocarp seedlings

\section{Diameter at Root Collar $\left(\mathrm{D}_{0}\right)$ and Height $(\mathrm{H})$ of the Dipterocarp Seedlings}

Diameter at root collar $\left(\mathrm{D}_{0}\right)$ and height $(\mathrm{H})$ of the six Dipterocarp seedlings, for the years 1 to 3 , significantly differed among the species in the open plot. $\mathrm{D}_{0}$ and $\mathrm{H}$ of $D$. alatus were the highest in the open plot after the first year of planting. Moreover, $\mathrm{D}_{0}$ of $D$. alatus $(6.04 \mathrm{~cm})$ was significantly higher than that of $S$. roxburgbii $(4.07 \mathrm{~cm})$ and $H$. odorata $(2.95 \mathrm{~cm})$, but their heights $(\mathrm{H})$ did not differ at ages 2 and 3 years. The $D$. alatus seedling experienced a good growth in the open area and its stem diameter $(7.20 \mathrm{~cm})$, at $30 \mathrm{~cm}$ above the ground, was larger than those of the Dipterocarp seedlings reported by Sakai et al. (2014). However, $\mathrm{D}_{0}$ and $\mathrm{H}$ of the 1 to 3-year-old $S$. roxburghii and $H$. odorata seedlings experienced a relatively higher growth at the open plot indicating their preference for brighter light conditions. $H$. odorata and S. roxburghii seedlings had good growths and were both tolerant to drought, suggesting that these can be planted in open areas.

At the $A$. mangium plot, the $\mathrm{D}_{0}$ of 1 -year-old $P$. stellata and $D$. alatus seedlings were significantly higher than those of other species. After $A$. mangium was thinned by $50 \%$, the $\mathrm{D}_{0}$ of $D$. alatus $(2.38 \mathrm{~cm})$ gradually increased and was the highest at 2 years after planting, but that of D. gracilis $(1.21 \mathrm{~cm})$ seedlings was the lowest. Reducing the $A$. mangium canopy positively influenced the $\mathrm{D}_{0}$ of $D$. alatus, $S$. roxburghii, H. odorata and P. stellata seedlings, but not of $D$. gracilis and $S$. gratissima seedlings which exhibited a lower growth rate. Moreover, their mortality rate was $100 \%$ in the open plot, 2 years after planting. Species vary in their responses to different light conditions (Hattori et al. 2009). The $\mathrm{D}_{0}$ and $\mathrm{DBH}$ of $D$. alatus and $H$. odorata in a $75 \%$ thinned Leucaena leucocephala plantation were higher than those in a 50\% thinned L. leucocephala plantation, while $\mathrm{D}_{0}$ and DBH of Shorea henryana in a 100\% thinned L. leucocephala plantation were higher than in a $75 \%$ and $50 \%$ thinned plantation (Sakai et al. 2014).

Height growth of the six Dipterocarp seedlings was significantly different among the species at the $A$. mangium plot. The $P$. stellata seedling was the tallest at ages1 and 2 years. Among the 3-year-old seedlings at the thinned A. mangium plot, S. roxburghii $(255.01 \mathrm{~cm})$ was the tallest but not different from $P$. stellata $(215.78 \mathrm{~cm})$, while $D$. gracilis $(138.87 \mathrm{~cm})$ was the shortest. $\mathrm{D}_{0}, \mathrm{H}$, and survival rate of $D$. gracilis seedling were low, indicating its unsuitability for mined out areas with poor soil and bright light conditions.

The seedlings of $S$. roxburgbii and $H$. odorata planted at the thinned $A$. mangium plot were taller than those planted in the open plot. Both species were the tallest when planted with nurse trees, an observation similar to that of Norisada et al. (2005). However, this result is contrary to that of Niamrat and Marod (2005), who indicated that the $H$. odorata seedlings planted in open areas were taller than those under a canopy of 4 and 20-year-old Eucalyptus camaldulensis stand. Similarly, the $H$. odorata seedling growth rate was higher in an open area compared to that in $A$. auriculuformis and E. camaldulensis plantations (Sakai et al. 2009). The good growth of $D$. alatus seedlings both in the open and $A$. mangium plots was also observed by Niamrat and Marod (2005). Soil properties of the post-mining area limited the tree growth and seedling establishment because of its low soil nutrients and high sand particle. 


\section{Diameter at root collar}
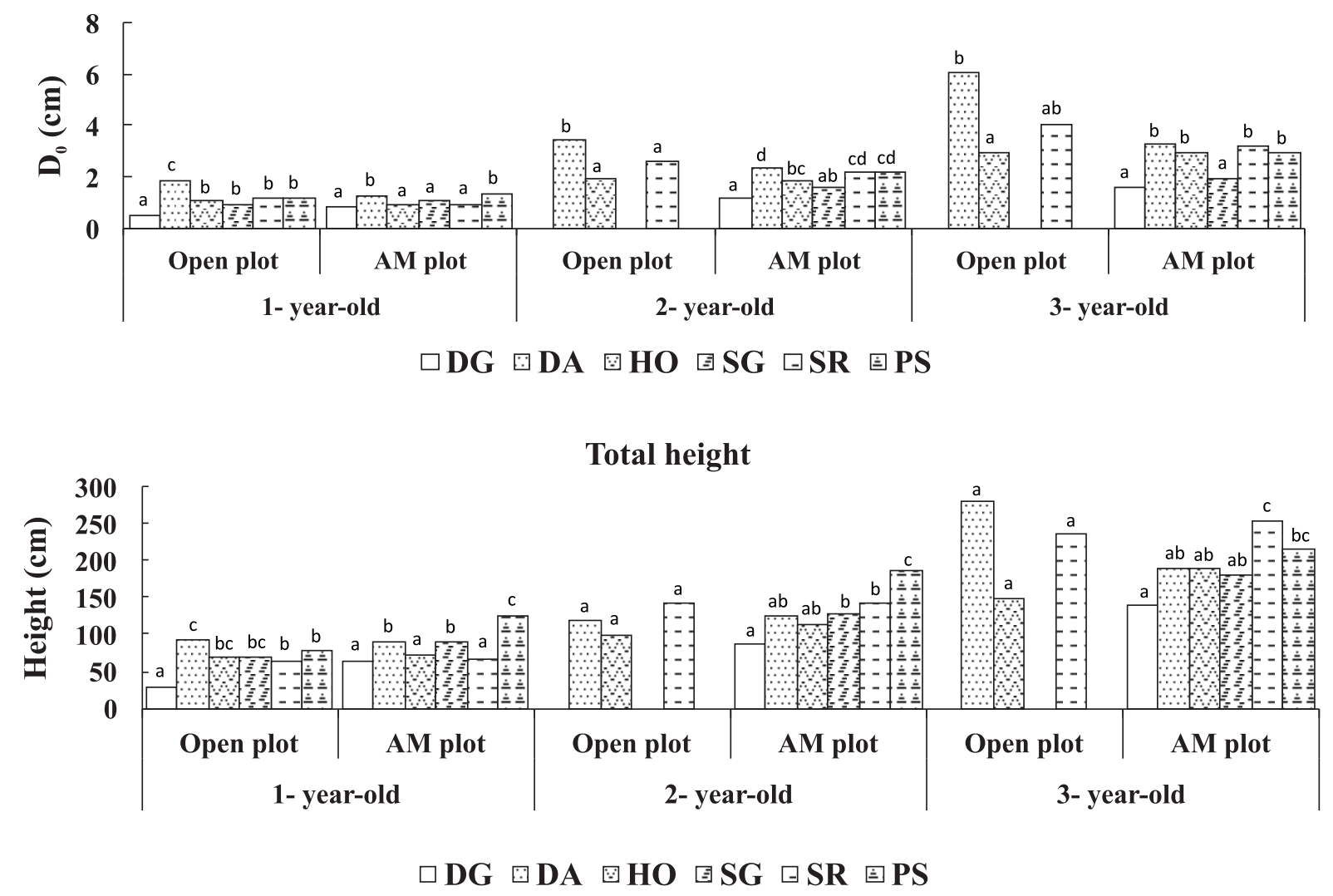

Figure 4 Diameter at root collar $\left(\mathrm{D}_{0}\right)$ and total height of Dipterocarp species at the open and $A$. mangium plots Notes: Different letters above bars indicate significant differences $(\mathrm{p}<0.05)$ among treatments by DMRT; $\mathrm{DG}=$ Diptertocarpus gracilis, $\mathrm{DA}=$ Dipterocarpus alatus, $\mathrm{SR}=$ Shorea roxburgii, $\mathrm{SG}=$ Shorea gratissima, $\mathrm{HO}=$ Hopea odorata, PS $=$ Parashorea stellata .

The 3-year-old Dipterocarp seedlings, growing under the $A$. mangium canopy, showed a high survival rate and satisfactory stem and height growth. Hence, rehabilitation of mining areas using Dipterocarp species should include A. mangium nurse trees as has been recommended in degraded sites (Norisada et al. 2005). A. mangium not only enhanced the growth and survival rates of Dipterocarp trees, but also improved the soil properties (Kongchum et al. 2016), particularly nitrogen, a crucial nutrient for seedling growth in degraded areas.

Fast-growing trees also play an important role in reducing the demand for wood from the natural forests (West 2014). A. mangium grows well and are widely used for restoring degraded areas (Lamb 2011). Thinning of $A$. mangium stands can improve both the growth and quality of the wood of the remaining $A$. mangium trees (Wongprom et al. 2013).

\section{Relative Growth Rate (RGR)}

RGR of the base diameter $\left(R_{G R}\right)$ in the open plot significantly differed among the 1year-old species, but not among the 2 and 3year-old (Table 4). RGR $\mathrm{R}_{\mathrm{D} 0}$ of a 1 -year-old S. roxburghii $(0.67 \mathrm{~cm} / \mathrm{cm} / \mathrm{yr})$ seedling was the highest followed by $D$. alatus $(0.55 \mathrm{~cm} / \mathrm{cm} / \mathrm{yr})$, P. stellata $(0.49 \mathrm{~cm} / \mathrm{cm} / \mathrm{yr}), S$. gratissima $(0.45$ $\mathrm{cm} / \mathrm{cm} / \mathrm{yr}), H$. odorata $(0.33) \mathrm{cm} / \mathrm{cm} / \mathrm{yr}$, and D. gracilis $(0.12 \mathrm{~cm} / \mathrm{cm} / \mathrm{yr})$. RGR of the height $\left(\mathrm{RGR}_{\mathrm{H}}\right)$ of all the 1 to 3-year-old Dipterocarp seedlings in the open area did not significantly differ $(p>0.05)$, but was the highest for the S. roxburgbii seedling $(0.58 \mathrm{~cm} / \mathrm{cm} / \mathrm{yr})$. The S. roxburgbii seedling growth both for $\mathrm{RGR}_{\mathrm{D} 0}$ and $\mathrm{RGR}_{\mathrm{H}}$ in the open area were greater than those of Dipterocarpus oblongifolius and Dryobalanops oblongifolia (Ang et al. 2003).

The $\mathrm{RGR}_{\mathrm{D} 0}$ of the 1-year-old Dipterocarp seedlings planted at the $A$. mangium plot was not significantly different among species, but for 
$\mathrm{RGR}_{\mathrm{H}}, \quad$ S. roxburghii $(0.71 \mathrm{~cm} / \mathrm{cm} / \mathrm{yr})$ and P. stellata $(0.70 \mathrm{~cm} / \mathrm{cm} / \mathrm{yr})$ seedlings had significantly higher $\mathrm{RGR}_{\mathrm{H}}$ than $D$. alatus $(0.31$ $\mathrm{cm} / \mathrm{cm} / \mathrm{yr}), \quad D$. gracilis $(0.16 \mathrm{~cm} / \mathrm{cm} / \mathrm{yr})$, H. odorata $(0.38 \mathrm{~cm} / \mathrm{cm} / \mathrm{yr})$ and $S$. gratissima $(0.38 \mathrm{~cm} / \mathrm{cm} / \mathrm{yr})$. After the $A$. mangium plantation was thinned by $50 \%$, the $\mathrm{RGR}_{\mathrm{D} 0}$ and $\mathrm{RGR}_{\mathrm{H}}$ values of 2 -year-old $S$. roxburgbii seedling were 0.91 and $0.75 \mathrm{~cm} / \mathrm{cm} / \mathrm{yr}$, respectively and were the highest. However, both $\mathrm{RGR}_{\mathrm{D} 0}$ and $\mathrm{RGR}_{\mathrm{H}}$ for $D$. gracilis seedlings $(0.36$ and 0.28 $\mathrm{cm} / \mathrm{cm} / \mathrm{yr}$, respectively) were the lowest.

After the removal of the $A$. mangium crown cover $D$. alatus and $H$. odorata seedlings attained a much taller height. The intensity of light reaching the seedlings had increased, leading to enhanced growth rates of the Dipterocarp (Hattori et al. 2009; Sakai et al. 2011) as well as non-Dipterocarp seedlings growing under the canopy (Sakai et al. 2011). The relative growth rates of the Dipterocarp seedlings also depend on the thinning intensity of the nurse trees, species type and methods of planting, line, gap or strip (Hattori et al. 2009; Sakai et al. 2009; Sakai et al. 2014). The $\mathrm{RGR}_{\mathrm{D} 0}$ and $\mathrm{RGR}_{\mathrm{H}}$ of $P$. stellata seedlings drastically decreased after the thinning of $A$. mangium, indicating its shade tolerant ability. Among the 3-year-old Dipterocarp seedlings planted at the $A$. mangium plot, $S$. roxburgbii had the highest $\mathrm{RGR}_{\mathrm{D} 0}$ and $\mathrm{RGR}_{\mathrm{H}}$. However, $\mathrm{RGR}_{\mathrm{D} 0}$ and $\mathrm{RGR}_{\mathrm{H}}$ of $S$. roxburgbii was relatively higher in the A. mangium stand. Similarly, $\mathrm{RGR}_{\mathrm{D} 0}$ and $\mathrm{RGR}_{\mathrm{H}}$ of $D$. alatus and $H$. odorata seedlings in the open was greater than that in the $A$. mangium stand, suggesting that $S$. roxburghii, D. alatus, and $H$. odorata can be planted in open areas, even under severe environmental stresses in postmining sites.

Table 4 Relative growth rate $(\mathrm{cm} / \mathrm{cm} / \mathrm{yr})$ of diameter at root collar $\left(\mathrm{D}_{0}\right)$ and height $(\mathrm{H})$ of Dipterocarp seedlings at the open and the $A$. mangium plots

\begin{tabular}{|c|c|c|c|c|c|}
\hline \multirow{2}{*}{$\begin{array}{c}\text { Age } \\
\text { (year) }\end{array}$} & \multirow{2}{*}{ Species } & \multicolumn{2}{|c|}{ Open plot } & \multicolumn{2}{|c|}{ A. mangium plot } \\
\hline & & $\mathrm{RGR}_{\mathrm{D} 0}$ & $\mathrm{RGR}_{\mathrm{H}}$ & $\mathrm{RGR}_{\mathrm{D} 0}$ & $\mathrm{RGR}_{\mathrm{H}}$ \\
\hline \multirow[t]{7}{*}{1} & Dipterocarpus gracilis & $0.12^{\mathrm{a}}$ & 0.26 & 0.35 & $0.16^{\mathrm{a}}$ \\
\hline & Dipterocarpus alatus & $0.55^{\mathrm{bc}}$ & 0.42 & 0.66 & $0.31^{\mathrm{a}}$ \\
\hline & Hopea odorata & $0.33^{\mathrm{ab}}$ & 0.33 & 0.56 & $0.38^{\mathrm{a}}$ \\
\hline & Shorea gratissima & $0.45^{b c}$ & 0.38 & 0.51 & $0.38^{\mathrm{a}}$ \\
\hline & Shorea roxburghii & $0.67^{c}$ & 0.44 & 0.73 & $0.71^{b}$ \\
\hline & Parashorea stellata & $0.49^{\mathrm{bc}}$ & 0.34 & 0.70 & $0.70^{\mathrm{b}}$ \\
\hline & F-value & $3.602^{*}$ & $0.742^{\mathrm{ns}}$ & $2.002^{\mathrm{ns}}$ & $5.776^{*}$ \\
\hline \multirow[t]{7}{*}{2} & Dipterocarpus gracilis & - & - & $0.36^{\mathrm{a}}$ & $0.28^{\mathrm{a}}$ \\
\hline & Dipterocarpus alatus & 0.64 & 0.44 & $0.62^{b c}$ & $0.33^{\mathrm{a}}$ \\
\hline & Hopea odorata & 0.57 & 0.33 & $0.73^{\mathrm{cd}}$ & $0.47^{\mathrm{a}}$ \\
\hline & Shorea gratissima & - & - & $0.40^{\mathrm{ab}}$ & $0.36^{\mathrm{a}}$ \\
\hline & Shorea roxburghii & 0.80 & 0.59 & $0.91^{\mathrm{d}}$ & $0.75^{\mathrm{b}}$ \\
\hline & Parashorea stellata & - & - & $0.49^{\mathrm{ab}}$ & $0.39^{a}$ \\
\hline & F-value & $1.755^{\mathrm{ns}}$ & $1.361^{\mathrm{ns}}$ & $9.335^{* *}$ & $6.843^{* *}$ \\
\hline \multirow[t]{7}{*}{3} & Dipterocarpus gracilis & - & - & $0.29^{\mathrm{ab}}$ & $0.33^{\mathrm{b}}$ \\
\hline & Dipterocarpus alatus & 0.56 & 0.64 & $0.31^{\mathrm{ab}}$ & $0.49^{\mathrm{bc}}$ \\
\hline & Hopea odorata & 0.43 & 0.39 & $0.45^{\mathrm{b}}$ & $0.50^{\mathrm{bc}}$ \\
\hline & Shorea gratissima & - & - & $0.21^{\mathrm{a}}$ & $0.35^{\mathrm{b}}$ \\
\hline & Shorea roxburghii & 0.44 & 0.67 & $0.41^{\mathrm{b}}$ & $0.58^{c}$ \\
\hline & Parashorea stellata & - & - & $0.30^{\mathrm{ab}}$ & $0.16^{\mathrm{a}}$ \\
\hline & F-value & $1.424^{\mathrm{ns}}$ & $2.705^{\mathrm{ns}}$ & $2.752^{*}$ & $9.548^{* *}$ \\
\hline
\end{tabular}

Notes: $*=$ Significantly different at $\mathrm{p}<0.05 ; * *=$ Significantly different at $\mathrm{p}<0.01$; ns $=$ non-significant difference at $\mathrm{p}>0.05$; different letters in the same column indicate significant difference by DMRT. 


\section{CONCLUSION}

Dipterocarp seedlings planted in the abandoned mining area in southern Thailand performed better with $A$. mangium as the nurse trees. Their survival rates in the $A$. mangium stand clearly improved and exceeded $75 \%$. In contrast, the Dipterocarp seedlings planted in the open plot had lower survival rates, except for $S$. roxburghii, which was moderate. The stem diameter at the root collar and the height of S. roxburgbii, $D$. alatus, $P$. stellata, and $H$. odorata seedlings were higher in the $A$. mangium plot than that in the open plots indicating that these species can be used to rehabilitate degraded lands. The stem diameter at root collar, height and relative growth rate of $S$. roxburghii seedlings were relatively high, indicating its suitability for rehabilitating mined out areas with poor soil conditions, with or without the use of nurse trees. Moreover, thinning intervention should also be practiced to improve the growth of Dipterocarp seedlings. Mixed plantation of fastgrowing trees and Dipterocarp species is therefore, recommended for rehabilitating degraded areas, for improving forest structure, diversity, soil properties and for promoting wood utilization of fast-growing trees.

\section{ACKNOWLEDGEMENTS}

This study was financially supported by the Kasetsart University Research and Development Institute (KURDI), Thailand. The author is grateful to the Associate Professor Dr. Ladawan Puangchit for her valuable suggestions and to the staff at the Phangnga Forestry Research Station for their assistance in the fieldwork.

\section{REFERENCES}

Ang LH, Ho WH, Honma T, Krishnapillay B. 2003. Planting trials of Shorea roxburghii in Peninsular Malaysia. In: Aminah H, Ani S, Sim HC, Krishnapillay B, editors. Proceedings of the seventh round-table conference on Dipterocarps: 2002 October 10-7. Kuala Lumpur (MY): Asia Pacific Association of Forestry Research Institutions (APAFRI). p. 154-61.

Appanah S, Lamb D, Durst P, Thaung TL, Sabogal C, Gritten D, ... Shono K. 2016. Forest landscape restoration for Asia-Pacific forests: A synthesis. Bangkok (TH): FAO and RECOFTC.

Bohre P, Chaubey OP. 2014. Restoration of degraded lands through plantation forests. Global J Sci Front Res 14(1):19-27.

Bray RH, Kurtz LT. 1945. Determination of total, organic, and available forms of phosphorus in soils. Soil Sci 59:39-45.

Budiharta S, Meijaard E, Erskine PD, Rondinini C, Pacifici M, Wilson KA. 2014. Restoring degraded tropical forests for carbon and biodiversity. Environ Res Lett 9:114020.

Budiharta S, Meijaard E, Gaveau DLA, Struebig MJ, Wilting A, Kramer-Schadt S, ... Wilson KA. 2018. Restoration to offset the impacts of developments at a landscape scale reveals opportunities, challenges and tough choices. Global Environ Chang 52:152-61.

Estefan G, Sommer R, Ryan J. 2013. Methods of soil, plant and water analysis: A manual for the West Asia and North Africa Region, $3^{\text {rd }}$ ed. Beirut (LB): ICARDA.

Ghazoul J. 2016. Dipterocarp biology, ecology, and conservation. Oxford (UK): Oxford University Press.

Hattori D, Kenzo D, Kendawang JJ, Irino KO, Tanaka S, Ichie T, ... Sakurai K. 2009. Effects of light intensity and soil physico-chemical properties on seedling mortality and growth of six dipterocarp species planted for rehabilitation of degraded grassland, secondary forest and logged forest in Sarawak, Malaysia. Jpn J For Environment 51(2):105-15.

Hattori D, Kenzo T, Yamauchi N, Irino KO, Kendawang JJ, Ninomiya I, Sakurai K. 2013. Effects of environmental factors on growth and morality of Parashoreamacrophylla (Dipterocarpaceae) planted on slopes and valleys in a degraded tropical secondary forest in Sarawak, Malaysia. J Soil Sci Plant Nutr 59:218-28.

Kenzo T, Yoneda R, Matsumoto Y, Azani AM, Majid MN. 2011. Growth and photosynthetic response of four Malaysian indigenous tree species under different light conditions. J Trop For Sci 23(3):271-81

Kettle CJ. 2010. Ecological consideration for using dipterocarps for restoration of lowland rainforest in Southeast Asia. Biodivers Conserv 19:1137-51.

Kongchum W, Poolsiri R, Kaitpraneet S, Wongprom J. 2016. Some soil properties after mining reclamation at Phangnga Forestry Research Station. In: $10^{\text {th }}$ Silviculture Seminar "Plantation towards Thailand's Eco-Economy. Proceedings: 2016 May 4-1; Bangkok. Bangkok (TH): Faculty of Forestry, Kasetsart University. p. 102-11. 
Lamb D. 2011. Regreening the bare hill: Tropical forest restoration in the Asia-Pacific region. Dordrecht (NL): Springer Dordrecht.

Lamb D. 2014. Large-scale forest restoration. In: Colfer CJP, Innes JL, Parrotta J, Sayer J, editors. The Earthscan Forest Library. Abingdon (UK): Routledge.

Lanuza O, Casanoves F, Zahawi RA, Celentano D, Delgado D, Holl KD. 2018. Litterfall and nutrient dynamics shift in tropical forest restoration sites after a decade of recovery. Biotropica 50(3):491-8.

Lestari DA, Fiqa AP, Fauziah F, Budiharta S. 2019. Growth evaluation of native tree species planted on post coal mining reclamation site in East Kalimantan, Indonesia. Biodiversitas 20:134-43.

Martpalakorn M. 1990. Tree species trials on mined spoils at Amphoe Takuapa, Changwat Phangnga [Dissertation]. Retrieved from Kasetsart University.

Niamrat W, Marod D. 2005. Seedling establishment of climax species under the Eucalyptus plantations and open areas. Thai J For 24:35-47.

Norisada M, Hitsuma G, Kuroda K, Yamanoshita T, Masumori M, Tang T, ... Kojima K. 2005. Acacia mangium, a nurse tree candidate for reforestation on degraded sandy soils in the Malay Penisula. For Sci 51(5):498-510.

Oktavia D, Setiadi Y, Hilwan I. 2015. The comparison of soil properties in heath forest and post-tin mined land: basic for ecosystem restoration. Procedia Environ Sci 28:124-31.

Parrotta JA. 1999. Productivity, nutrient cycling, and succession in single and mixed-species plantations of Casuarina equisetifolia, Eucalyptus robusta, and
Leucaena leucocephala in Puerto Rico. For Ecol Manage 124:45-77.

Sakai A, Visaratana T, Vacharangkura T, Thai-ngam R, Tanaka N, Ishizuka M, Nakamura S. 2009. Effects of species and spacing of fast-growing nurse trees on growth of an indigenous tree, Hopea odorata Roxb., in Northeast Thailand. For Ecol Manage 257:644-52.

Sakai A, Visaratana T, Vacharangkura T, Ishizuka M, Nakamura S. 2011. Growth performances of three indigenous tree species planted in a mature Acacia mangium plantation with different canopy openness under a tropical monsoon climate. JARQ 45(3):317-26.

Sakai A, Visaratana T, Vacharangkura T, Thai-ngam R, Nakamura S. 2014. Growth performance of four dipterocarp species planted in a Leucaena leucocephala plantation and in an open site on degraded land under a tropical monsoon climate. JARQ 48(1):95104.

USDA. 1967. Soil laboratory method and procedures for collecting soil sample. Washington DC (US): USDASoil Conservation Services, Soil Surv Invest Rep No.1. $63 \mathrm{p}$.

West PW. 2014. Growing plantation forests. New York (US): Springer Cham Heidelberg.

Wongprom J, Maelim S, Teejuntuk S, Sommeechai M. 2013. Effects of thinning on growth and yield of Acacia mangium Willd. under naturally regenerated on abandoned mining area in Phang-Nga Forestry Research Station. Thai J For 32:142-51.

Yeong KL, Reynolds G, Hill JK. 2016. Enrichment planting to improve habitat quality and conservation value of tropical rain fragments. Biodivers Conserv 25:957-73. 